\section{CORRESPONDENCE}

\section{Primates Threatened}

SIR,-The growing threat to some species of non-human primates incurred by circumstances in their natural habitats is not well known even to those sciontists who have recognized their value for biomedical laboratory investigations.

Growing human populations with urbanization and agricultural expansion are intruding upon primate animal habitats. Indigenous humans utilize lower primates extensively for food. Trappers and shippers handle animals for export in wasteful ways. Chimpanzee mothers are often shot dead in order to obtain single babies for export. Many animals die of diseases contracted after they are trapped.

Although knowledgeable scientists have recognized this threat to one of their important resources for some time, no effective action has been taken until recently. The following resolution was adopted by our Committee of Scientists for the Use of Primates in Medical Research in January 1968 and was presented to the surgeon general with the request that the matter of primate conservation be brought before the World Health Assembly. Previously on the initiative of our committee the same resolution was adopted by the members of a European symposium on the Use of Primates in Medical Research in Lyon in November 1967. Support for the resolution was also obtained at the recent second congress of the International Primatological Society meeting in Atlanta, Georgia, and from a meeting in Now York of interested scientists sponsored by the New York Zoological Society and the International Union for the Conservation of Natural Resources. The resolution reads as follows:

"Whereas there is general recognition by the scientific community of the importance of nonhuman primates for bio-medical purposes,

"Whereas there is a widespread belief among. competent scientists that some primate species are in danger of depletion as a result of capturing and of encroachment on natural habitats by developing human populations,

"Therefore it is requested that WHO convene a meeting of a scientific group as soon as possible to examine the problem in detail and recommend measures designed to ensure the continued supply of these animals for the welfare of man and also for the conservation of the species."

The United States delegation to the World Health Assembly introduced the topic for discussion and this has now established conservation of primato species to be a matter of international concern. The implementation of ways and means to protect primate populations will be a thorny and prolonged process so that these beginnings are occurring none too early. Your readers may be interested in these recent developments because (i) they evidence the beginning of cooperation among members of diverse disciplines (medicine, zoology, anthropology, consorvation, etc.) and (ii) they offer hope that certain endangered species will be protected before it becomes too late. Strong support by the scientific community will be required to convert platitudes into successful procedures.

Edward T. Goldsmith, Chairman, Committee of Scientists for the Use of Primates in Medical Research.

The New York Hospital-

Cornell Medical Center,

525 East 68th Street,

New York, NY.

\title{
University Government
}

SIR,-Two months have passed since you published the last of a series of very provoking articles drawing attention to the many weaknesses in university government, and we have waited patiently and expectantly for some sort of reaction from your readers. Not one word in reply has yet been published. Does this silence mean that the academic staff of British universities are happy with the present form of government, is it the result of a fear of reprisal, or have all the letters you have received been unprintable? We had hoped that there would be some indication in your columns of how university teachers feel about the present regimes they work under. Perhaps you will allow us space to make a few observations which may provoke a few academics into revealing their feelings on this subject.

In this country there are indications of a growing awareness amongst academics that the current system of governing the affairs of the university has outlived its usefulness and that some radical changes in its structure are badly needed. It is clear that the ruling body (be it called senate or, more modestly, professorial board, or any other name) in its present constitution is not only a travesty of equity but also an undisguised affront to common sense - not to mention its ineongruously autocratic character, out of place in a predominantly democratic setting. No matter how many plausible arguments can be adduced in favour of retaining that outmoded body, they cannot but be spurious-for there is no escape from the fact that the vast majority of teachers (who are, after all, the core of the institution) have practically no say in matters which affect both the wider academic policies and their own standing in the university. This is an anomaly which requires our most urgent attention.

Ideally, one would expect the initiative for a reform to emanate from within the senate (or professorial board) itself, but it appears that, naturally enough, no early positive move is forthcoming from that quarter. It would, of course, be false to surmise that all professors are unqualifiedly happy about the present system. It can be taken for granted that there are some mernbers on the senate who have for some considerable time felt their semi-dictatorial status as an intellectual and moral handicap rather than a blessing, and who would welcome a process of liberalization - but they are sadly in a minority and they would require "outside" help to overcome the inertia of the old guard.

We have learnt that in some European countries (notably Germany and France) the university is in a state of ideational siege. The traditional German "feudal" system, in which professors appear as paragons of academic virtues unassailable in their departmental fortresses, is being questioned with all the seriousness the situation demands and practical policies are in the process of implementation. Academic France is likewise experiencing a fruitful reappraisal of its way of life and the omens are favourable for a revision of the old system. For example, the recommendations of the "national colloquy" at the University of Caen in 1966 are a trenchant rebuttal of the status quo and are, in essence, an appeal for the adoption of the more liberal American model in higher education.

Is it too much to hope that similar changes will soon take place in the universities of Britain and the Commonwealth ?

$$
\text { Yours, etc., }
$$

Department of Philosophy, and

\section{K. B. Pflaum}

Department of Zoology,

University of Auckland,

PO Box 2175,

Auckland, New Zealand.
M. C. Mitler 